\title{
PENGARUH KEPEMIMPINAN DAN MOTIVASI KERJA TERHADAP KEDISIPLINAN APARATUR DESA DI KECAMATAN KASIMBAR
}

\author{
Sujarwadi \\ Email: sujar9548@gmail.com
}

(Dosen Fakultas Ekonomi Universitas Alkhairaat)

\begin{abstract}
ABSTRAK
Penelitian ini bertujuan untuk mengetahui dan menganalisis pengaruh Kepemimpinan Terhadap Kedisipinan Aparatur Desa di Kec. Kasimbar, pengaruh Motivasi Kerja terhadap Kedisipinan Aparatur Desa di Kec. Kasimbar. Sampel dalam penelitian ini adalah seluruh populasi yaitu 78 aparatur di tiga desa kec. kasimbar. Tehnik ini dipakai dengan tujuan agar dapat memperoleh informasi yang lebih lengkap tentang kondisi sebenarnya. Alat analisis yang digunakan adalah analisis regresi linear berganda. Hasil penelitian menunjukkan bahwa: hasil perhitungan diperoleh Fhitung $=22.432$ pada taraf nyata $\alpha=0,05$ atau Sig $F<0,05$. nilai signifgikansi $F=0,000$. Dengan demikian dapat dinyatakan bahwa secara bersama-sama (simultan) variabel bebas mempunyai pengaruh yang signifikan terhadap variabel tidak bebasnya; kepemimpinan berpengaruh signifikan terhadap kedisiplinan aparatur desa dengan nilai sig 0.003; motivasi kerja tidak berpengaruh signifikan terhadap kedisipinan aparatur desa dengan nilai sig 0.244.
\end{abstract}

Kata Kunci: Kepemimpinan, Motivasi Kerja, Kedisiplinan.

\section{LATAR BELAKANG}

Menurut (Qosim, 2019) Salah satu agenda reformasi nasional yang dicanangkan oleh pemerintah adalah yang menyangkut otonomi daerah. Penyelenggaraan pemerintahan desa tidak terpisahkan dari penyelenggaraan otonomi daerah. Pemerintahan desa merupakan unit terdepan dalam pelayanan kepada masyarakat serta tombak strategis untuk keberhasilan semua program. Karena itu, upaya untuk memperkuat desa merupakan langkah mempercepat terwujudnya kesejahteraan masyarakat. Penyelenggaraan pemerintahan desa merupakan sub sistem dari sistem penyelenggaraan pemerintahan, sehingga desa memiliki kewenangan untuk mengatur dan mengurus kepentingan masyarakatnya.

Pemerintah desa dalam melaksanakan tugas pembangunan dan penyelenggaraan pelayanan kepada masyarakat harus benar-benar memperhatikan hubungan kemitraan kerja dalam penyelenggaraan pemerintahannya.
Kemitraan dalam penyelenggaraan pemerintahan desa dimaksud berarti bahwa dalam melaksanakan tugas pembangunan maupun pemberian pelayanan kepada masyarakat, semua aparatur pemerintahan desa, baik itu kepala desa, perangkat desa, dan Badan Perwakilan Desa (BPD) harus benar-benar memahami kapasitas yang menjadi kewenangan maupun tugasnya masing-masing. Sehingga dalam melaksanakan penyelenggaraan pemerintahan desa semua aparatur pemerintah tersebut dapat bersinergi dan bermitra dengan baik, serta tepat dalam meningkatkan penyelenggaraan pemerintahan desa yang profesional dan akuntabel.

Upaya membentuk karakter aparatur negara yang unggul dan berkualitas serta mampu mengembangkan potensi kepribadian khususnya dalam menanamkan nilai dan prinsip moral yang baik dalam melaksanakan tugas dan fungsi selaku aparatur pemerintahan desa. Praktek penyelenggaraan pemerintahan desa di Indonesia 
memang seringkali mengalami persoalanpersoalan yang timbul terkait dengan hubungan tersebut, termasuk tentang sikap disiplin perangkat desa dalam menjalankan tugas dan fungsi. Untuk mencapai hasil yang baik dalam menjalakan tugas dan fungsi, perangkat desa perlu adanya disiplin yang baik dari para anggota perangkat desa yang bersangkutan. Disiplin yang baik mencerminkan besarnya rasa tanggung jawab seseorang terhadap tugas-tugas yang diberikan kepadanya. Disamping itu disiplin dapat dijadikan alat untuk membangun kepribadian perangkat desa dimana apabila lingkungan kerjanya baik maka akan berdampak positif bagi pribadi perangkat desa tersebut.

Realita yang terjadi di lapangan marak terdapat kasus-kasus yang menunjukkan perangkat desa di Kec. Kasimbar belum menjalankan tugas dan fungsi secara disiplin. Salah satunya yaitu kinerja perangkat desa yang kurang maksimal karena sering melakukan aktivitas lain yang tidak sesuai dengan tugas dan fungsi, sehingga aparatur desa sering terlambat masuk kantor.

Dapat disimpulkan dari berbagai kasus di atas yang mengangkut perangkat desa dalam menjalankan tugas dan fungsi berubah alih menjadi tindakan pidana maupun penyelewengan kekuasaan. Masyarakat harus diajak ikut andil untuk mengawasi kinerja perangkat desa dalam menjalankan tugas dan fungsi. Tujuan penelitian ini adalah untuk mendeskripsikan implementasi karakter disiplin pada perangkat desa dalam menjalankan tugas dan fungsi di Desa Kec. Kasimbar Kab. Parimo. Sekaligus mengetahui kendala dan solusi pelaksanaan karakter disiplin perangkat desa dalam menjalankan tugas dan fungsi. Manfaat penelitian ini diharapkan dapat memberikan kontribusi bagi perkembangan konsep mengenai implementasi karakter disiplin perangkat desa dalam menjalankan tugas dan fungsi.

Mengingat kompleksnya aspek-aspek atau bidang yang hendak dibangun ditingkat pemerintahan terendah tersebut, maka salah satu aspek yang terlebih dahulu perlu dibangun adalah peningkatan kemampuan aparat pemerintah desa serta motivasi kerja yang masih rendah dalam pelaksanaan tugas-tugas administrasipemerintahan, disamping memperkuat partisipasi masyarakat dan kelembagaannya sertaaspek-aspek lainnya.Fenomena yang terjadi menggambarkan bahwa kinerja aparatur pada instansi pemerintah desa belum maksimal disebabkan kurangnya disiplin dan motivasi.

Hal ini terbukti dari pelaksanaan tugastugas aparat desa kasimbar tidak terlaksana dengan baik dan konsisten sesuai ketentuan,sebagaimana tersebut diatas, maka hal itu terjadi karena adanya pengaruh berbagai faktor, antara lain terutama faktor kemampuan sumber daya dan rendah motivasi kerja aparat desa sebagai penyelenggara yang belum optimal.

Berdasarkan uraian latar belakang di atas, maka permasalahan dalam penelitian ini dapat di rumuskan:

1. Apakah kepemimpinan dan motivasi kerja secara simultan mempunyai pengaruh signifikan terhadap kedisiplinan aparatur desa?

2. Apakah kepemimpinan secara parsial mempunyai pengaruh signifikan terhadap kedisiplinan aparatur desa?

3. Apakah motivasi kerja secara parsial mempunyai pengaruh signifikan terhadap kedisiplinan aparatur desa?

\section{KAJIAN PUSTAKA}

\section{Kepemimpinan}

Menurut House dalam Yukl, (2009:4) mengatakan bahwa: Kepemimpinan adalah kemampuan individu untuk mempengaruhi, memotivasi, dan membuat orang lain mampu memberikan kontribusinya demi efektivitas dan keberhasilan organisasi. Jadi dari pendapat House dapat dikatakan bahwa kepemimpinan merupakan cara mempengaruhi dan memotivasi orang lain agar orang tersebut mau berkontribusi untuk keberhasilan organisasi.

\section{Tipe-tipe Kepemimpinan}

Menurut (Marjun, 2019) Kepemimpinan (leadership) dapat dikatakan sebagai cara dari seorang pemimpin (leader), dalam mengarahkan, mendorong, dan mengatur semua unsur-unsur 
didalam suatu organisasi untuk mewujudkan suatu tujuan yang akan dicapai, sehingga menghasilkan kinerja pegawai yang maksimal. Keberhasilan seorang pemimpin dalam mempengaruhi perilaku bawahan banyak dipengaruhi oleh gaya kepemimpinan. Beberapa ahli mengemukakan pendapat tentang macam-macam gaya kepemimpinan, adalah sebagai berikut :

1. Gaya kepemimpinan menurut pendapat Hasibuan (2007:170) gaya kepemimpinan dibagi menjadi tiga bagian, yaitu :

a. Kepemimpinan Otoriter adalah jika kekuasaan atau wewenang, sebagian besar mutlak tetap berada pada pimpinan atau kalau pimpinan itu menganut sistem sentralisasi wewenang. Pengambilan keputusan dan kebijaksanaan hanya ditetapkan sendiri oleh pemimpin, bawahan tidak diikutsertakan untuk memberikan saran, ide, dan pertimbangan dalam proses pengambilan keputusan. Orientasi kepemimpinannya difokuskan hanya untuk peningkatan produktivitas kerja karyawan dengan kurang memperhatikan perasaan dan kesejahteraan bawahan.

b. Kepemimpinan Partisipatif adalah apabila dalam kepemimpinannya dilakukan dengan cara persuasif, menciptakan kerja sama yang serasi, menumbuhkan loyalitas, dan partisipasi para bawahan. Pemimpin memotivasi bawahan agar merasa ikut memiliki perusahaan. Bawahan harus berpartisipasi memberikan saran, ide, dan pertimbangan dalam proses pengambilan keputusan. Pemimpin dengan gaya partisipatif akan mendorong kemampuan bawahan mengambil keputusan. Dengan demikian, pimpinan akan selalu membina bawahan untuk menerima tanggung jawab yang lebih besar.

c. Kepemimpinan Delegatif apabila seorang pemimpin mendelegasikan wewenangnya kepada bawahan dengan agak lengkap. Dengan demikian, bawahan dapat mengambil keputusan dan kebijaksanaan dengan bebas atau leluasa dalam melaksanakan pekerjaannya. Pemimpin tidak peduli cara bawahan mengambil keputusan dan mengerjakan pekerjaannya, sepenuhnya diserahkan kepada bawahan. Pada prinsipnya pemimpin bersikap menyerahkan dan mengatakan kepada bawahan inilah pekerjaan yang harus saudara kerjakan, saya tidak peduli, terserah saudara bagaimana mengerjakannya asal pekerjaan tersebut bisa diselesaikan dengan baik. Dalam hal ini bawahan dituntut memiliki kematangan dalam pekerjan (kemampuan) dan kematangan psikologis (kemauan). Kematangan pekerjaan dikaitkan dengan kemampuan untuk melakukan sesuatu yang berdasarkan pengetahuan dan keterampilan. Kematangan psikologis dikaitkan dengan kemauan atau motivasi untuk melakukan sesuatu yang erat kaitannya dengan rasa yakin dan keterikatan.

\section{Motivasi Kerja Motivasi}

Motivasi berasal dari kata Latin movere yang berarti dorongan atau daya penggerak. Motivasi dalam manajemen hanya ditujukan pada sumber daya manusia umumnya dan bawahan khususnya. Hasibuan (2007:95) mengatakan motivasi adalah pemberian daya penggerak yang menciptakan kegairahan kerja seseorang, agar mereka mau bekerja sama, bekerja efektif dan terintegrasi dengan segala daya upayanya untuk mencapai kepuasan.

Sedangkan menurut Robbins (2006:213) dalam bukunya Perilaku Organisasi, mendefinisikan Motivasi sebagai proses yang ikut menentukan intensitas, arah, dan ketekunan individu dalam usaha mencapai sasaran. Jadi motivasi merupakan upaya yang ada dalam diri seseorang dalam memenuhi kebutuhannya guna mencapai tujuan organisasi.

\section{Teori-Teori Motivasi}

Menurut Teori kebutuhan McClelland dalam Robbins (2006:222), kebutuhan dibagi menjadi tiga bagian yaiu: 
1. Kebutuhan akan berprestasi: dorongan untuk unggul, untuk berprestasi berdasar seperangkat standar, untuk berusaha keras supaya sukses.

2. Kebutuhan akan kekuasaan: kebutuhan untuk membuat orang lain berperilaku dalam suatu cara yang sedemikian rupa sehingga mereka tidak akan berprilaku sebaliknya.

3. Kebutuhan akan kelompok pertemanan: hasrat untuk hubungan antarpribadi yang ramah.

Pada umumnya manusia terdorong atau termotivasi dalam bekerja, disebabkan oleh berbagai macam tindakan kebutuhan yang diinginkan. Begitu juga dengan kebutuhan dasar nya terpengaruhi, maka akan muncul kebutuhan yang lain dengan demikian untuk merangsang karyawan agar lebih bersemangat dalam melaksanakan pekerjaan nya haruslah dapat dipenuhi kebutuhan dasar nya terlebih dahulu dan juga kebutuhan lain nya. Menurut (Azis, 2019) Kompensasi dapat meningkatkan kinerja karyawan. Ketika kinerja karyawan meningkat, maka prestasi dalam bekerja pun dapat dicapai. Dengan tercapainya prestasi kerja yang diraih karyawan akan turut meningkat dan kinerja perusahaan turut tercapai. McClelland dalam Robbins (2006:222)

4. Mc. Clelland dengan Teori Motivasi Prestasi

Teori ini berpendapat bahwa pegawai mempunyai cadangan energi potensial. Bagaimana energi dilepaskan dan digunakan tergantung pada kekuatan dorongan motivasi seseorang dan situasi serta peluang yang tersedia. Menurut teori ini ada tiga komponen dasar yang dapat digunakan untuk memotivasi orang bekerja, yaitu kebutuhan :

a. Kebutuhan akan prestasi (need for achievement $)=(n . A c h)$ Kebutuhan akan Prestasi merupakan daya penggerak yang memotivasi semangat bekerja seseorang. Karena itu n.Ach ini akan mendorong seseorang untuk mengembangkan kreativitas dan mengarahkan semua kemampuan serta energi yang dimilikinya demi mencapai prestasi kerja yang optimal.

b. Kebutuhan akan afiliasi (need for affiliation) $=$ (n.Af) Kebutuhan akan afiliasi menjadi daya penggerak yang akan memotivasi semangat bekerja seseorang pegawai, karena kebutuhan n.Af ini yang merangsang gairah kerja seseorang pegawai, yang akan memotivasi dan mengembangkan dirinya serta memanfaatkan semua energinya untuk menyelesaikan tugastugasnya.

c. Kebutuhan akan kekuasaan (need for power) $=$ (n.Pow) Kebutuhan akan kekuasaan merupakan daya penggerak yang memotivasi semangat kerja seseorang pegawai. Karena itu n.Pow ini merangsang dan memotivasi gairah kerja seseorang serta mengerahkan semua kemampuan demi mencapai kekuasaan atau kedudukan yang terbaik dalam organisasi.

\section{Kedisiplinan}

Disiplin kerja adalah suatu alat yang digunakan para manajer untuk berko-munikasi dengan karyawan agar mereka bersedia mengubah suatu perilaku serta sebagai suatu upaya meningkatkan kesadaran dan kesediaan seseorang mentaati semua peraturan perusahaan dan normanorma sosial yang berlaku (Rivai, 2010:825).

\section{Indikator Disiplin Kerja}

Menurut Singodimejo dalam Sutrisno (2011:94) adalah sebagai berikut:

1. Taat terhadap aturan waktu Dilihat dari jam masuk kerja, jam pulang, dan jam istirahat yang tepat waktu sesuai dengan aturan yang berlaku di perusahaan.

2. Taat terhadap peraturan perusahaan Peraturan dasar tentang cara berpakaian, dan bertingkah laku dalam pekerjaan.

3. Taat terhadap aturan perilaku dalam pekerjaan Ditunjukan dengan cara-cara melakukan pekerjaan-pekerjaan sesuai dengan jabatan, tugas, dan tanggung jawab serta cara berhubungan dengan unit kerja lain.

\section{Hubungan Antar Variabel}

\section{Hubungan Variabel Kepemimpinan dengan} Kedisiplinan

Setiap pimpinan selalu berusaha agar para bawahannya mempunyai disiplin yang baik. Seorang pimpinan dikatakan efektif dalam kepemimpinannya, jika para bawahannya berdisiplin baik. Teladan pimpinan sangat 
berperan dalam menentukan kedisiplinan karyawan karena pimpinan dijadikan teladan dan panutan oleh para bawahannya. Pimpinan harus memberi contoh yang baik, berdisplin baik, jujur, adil, serta sesuai kata dengan perbuatan. Dengan teladan pimpinan yang baik, kedisiplinan bawahanpun akan ikut baik (Hasibuan, 2012).

\section{Hubungan Variabel Motivasi dengan Kedisiplinan}

Motivasi merupakan sebuah keahlian dalam mengarahkan karyawan pada tujuan organisasi agar mau bekerja dan berusaha sehingga keinginan para karyawan dan tujuan organisasi dapat tercapai. Motivasi seseorang melakukan suatu pekerjaan karena adanya suatu kebutuhan hidup yang harus dipenuhi. Kebutuhan ini dapat berupa kebutuhan ekonomis yaitu untuk memperoleh uang, sedangkan kebutuhan nonekonomis dapat diartikan sebagai kebutuhan untuk memperoleh penghargaan dan keinginan lebih maju.

Dengan segala kebutuhan tersebut, seseorang dituntut untuk lebih giat dan aktif dalam bekerja, untuk mencapai hal ini diperlukan adanya motivasi dalam melakukan pekerjaan, karena dapat mendorong seseorang bekerja dan selalu berkeinginan untuk melanjutkan usahanya. Oleh karena itu jika pegawai yang mempunyai motivasi kerja yang tinggi biasanya mempunyai kinerja yang tinggi pula.

\section{METODE PENILITIAN}

\section{Populasi}

Populasi adalah wilayah generalisasi yang terdiri atas: obyek/subyek yang mempunyai kualitas dan karakteristik tertentu yang ditetapkan oleh peneliti untuk dipelajari dan kemudian ditarik kesimpulannya (Sugiyono, 2006:72). Berdasarkan pengertian tersebut, maka yang menjadi populasi dalam penelitian ini adalah seluruh aparatur desa di tiga desa yang ada di Kec. Kasimbar, yang dinilai adalah desa yang mewakili populasi jumlah penduduk terbanyak dari 15 desa yang telah pemekaran, sehingga peneliti menjadikan populasi penelitian di tiga desa.

Tabel 1. Popilasi Penilitian

\begin{tabular}{|l|l|c|}
\hline No & \multicolumn{1}{|c|}{ SATKER } & $\begin{array}{c}\text { Jumlah } \\
\text { Aparatur Desa }\end{array}$ \\
\hline 1. & Aparatur Desa Kasimbar & 26 Orang \\
\hline 2. & $\begin{array}{l}\text { Aparatur Desa Kasimbar } \\
\text { Utara }\end{array}$ & 26 Orang \\
\hline 3. & Aparatur Desa Sendana & 26 Orang \\
\hline \multicolumn{2}{|c|}{ Jumlah } & 78 Orang \\
\hline
\end{tabular}

Berdasarkan Tabel 1. di atas, maka dapat diketahui jumlah populasi pada penelitian ini sebanyak 78 orang. Mengingat jumlah populasi penelitian pada Aparatur di Desa kec. Kasimbar relatif terbatas, maka atas pertimbangan untuk menjaga kerepresentatifan hasil penelitian, peneliti memutuskan untuk menetapkan keseluruhan populasi penelitian sebagai sampel penelitian dengan menggunakan sampel jenuh (sensus) yaitu teknik sampel yang menjadikan seluruh populasi menjadi sampel (Sugiyono, 2009:76).

\section{Operasionalisasi Variabel}

Operasionalisasi variabel adalah suatu cara untuk mengukur suatu konsep dan bagaimana caranya sebuah konsep diukur sehingga terdapat variabel-variabel yang dapat menyebabkan masalah lain dari variabel lain yang situasi dan kondisinya tergantung pada variabel lain.

1. Kepeimpinan (X1)

a. Kepemimpinan Otoriter adalah jika kekuasaan atau wewenang, sebagian besar mutlak tetap berada pada pimpinan atau kalau pimpinan itu menganut sistem sentralisasi wewenang.

b. Kepemimpinan Partisipatif adalah apabila dalam kepemimpinannya dilakukan dengan cara persuasif, menciptakan kerja sama yang serasi, menumbuhkan loyalitas, dan partisipasi para bawahan.

c. Kepemimpinan Delegatif apabila seorang pemimpin mendelegasikan wewenangnya kepada bawahan dengan agak lengkap.

2. Motivasi Kerja (X2)

a. Kebutuhan akan berprestasi: dorongan untuk unggul, untuk berprestasi berdasar seperangkat standar, untuk berusaha keras supaya sukses.

b. Kebutuhan akan afiliasi menjadi daya penggerak yang akan memotivasi semangat 
bekerja seseorang pegawai, karena kebutuhan n.Af ini yang merangsang gairah kerja seseorang pegawai, yang akan memotivasi dan mengembangkan dirinya serta memanfaatkan semua energinya untuk menyelesaikan tugas-tugasnya.

c. Kebutuhan akan kekuasaan merupakan daya penggerak yang memotivasi semangat kerja seseorang pegawai. Karena itu n.Pow ini merangsang dan memotivasi gairah kerja seseorang serta mengerahkan semua kemampuan demi mencapai kekuasaan atau kedudukan yang terbaik dalam organisasi.

3. Kedisiplinan Aparatur Desa

a. Taat terhadap aturan waktu Dilihat dari jam masuk kerja, jam pulang, dan jam istirahat yang tepat waktu sesuai dengan aturan yang berlaku di perusahaan.

b. Taat terhadap peraturan perusahaan Peraturan dasar tentang cara berpakaian, dan bertingkah laku dalam pekerjaan.

c. Taat terhadap aturan perilaku dalam pekerjaan Ditunjukan dengan cara-cara melakukan pekerjaan-pekerjaan sesuai dengan jabatan, tugas, dan tanggung jawab serta cara berhubungan dengan unit kerja lain.

\section{Uji Validitas}

Uji validitas dilakukan untuk mengukur pernyataan yang ada dalam kuisioner.Suatu pernyataan dianggap valid jika pernyataan tersebut mampu mengungkapkan apa yang akan diukur. Valid berarti instrumen tersebut dapat digunakan untuk mengukur apa yang harus diukur, atau ada kesesuaian antara alat ukur dengan yang diukur.

Seperti yang dikemukakan oleh Sugiyono (2009: 109) bahwa instrumen yang valid berarti alat ukur yang digunakan untuk mendapatkan data itu valid. Uji validitas dilakukan dengan cara mengkorelasikan masing-masing pernyataan dengan jumlah skor totalnya.

Validitas dapat diketahui dengan cara membandingkan nilai Corrected item-Total Correlation dengan nilai r-kritis sesuai kriteria. Menurut Sugiyono (2006: 124), bahwa bilamana koefisien antara skor suatu indikator dengan skor total seluruh indikator adalah positif dan lebih besar $0,3 \quad(r \geq 0,3) \quad$ maka instrument tersebut dianggap valid.

\section{Uji Keandalan (Test of Reliability)}

Instrumen penelitian selain valid, juga harus dapat diandalkan (reliable), instrumen dapat dikatakan reliabel jika alat tersebut menghasilkan nilai-nilai yang konsisten, dengan demikian instrumen ini dapat dipakai dengan aman karena dapat bekerja dengan baik pada waktu yang berbeda dengan kondisi yang berbeda ( Sugiyono, 2006 : 109). Dengan kata lain reliabilitas menunjukkan sejauh mana pengukuran dapat memberikan hasil yang tidak berbeda bila dilakukan pengukuran kembali pada subjek yang sama. Dalam penelitian ini dilakukan uji reliabilitas internal dengan menggunkan koefisien alpha cronbach $(\alpha)$. Suatu instrumen disebut reliabel apabila alpha cronbach lebih besar dari 0,60 (Sugiyono, 2006 : 126).

Tabel 2.

Reliability Instrument

\begin{tabular}{|c|l|c|c|}
\hline No & \multicolumn{1}{|c|}{ Variabel } & $\begin{array}{c}\text { Cronbach's } \\
\text { Alpha }\end{array}$ & Keterangan \\
\hline 1 & Kepemimpinan & 0,699 & Reliabel \\
\hline 2 & Motivasi Kerja & 0,728 & Reliabel \\
\hline 3 & $\begin{array}{l}\text { Kedisiplinan } \\
\text { Aparatur Desa }\end{array}$ & 0,706 & Reliabel \\
\hline
\end{tabular}

\section{Uji Asumsi Klasik}

\section{Uji Normalitas}

Tujuan uji normalitas adalah untuk mengetahui apakah distribusi sebuah data mengikuti atau mendekati distribusi normal.Uji normalitas bertujuan untuk menguji apakah model regresi berdistribusi normal. Uji normalitas dapat dilakukan dengan analisis gambar dilihat dari titik-titik yang menyebar disekitar garis diagonal yakni distribusi data dengan bentuk lonceng dan distribusi data tersebut tidak menceng ke kiri atau menceng ke kanan.

Adapun dasar pengambilan keputusan adalah:

1. Jilka data tersebar disekitar garis diagonal dan mengikuti arah garis diagonal maka model regresi memenuhi asumsi normalitas.

2. Jika menyebar jauh dari diagonal maka model regresi tidak memenuhi asumsi normalitas. 
Dengan bantuan program statistik SPSS 16 hasil Uji Normalitas, data dapat dilihat pada titik sebaran data yang dihasilkan dalam penelitian ini, sehingga dapat disimpulkan bahwa data dalam penelitian ini adalah data normal atau memenuhi asumsi normalitas berdasarkan dasar pengambilan keputusan yang telah disebutkan diatas. Adapun hasil dari uji normalitas dapat di lihat pada gambar berikut ini:

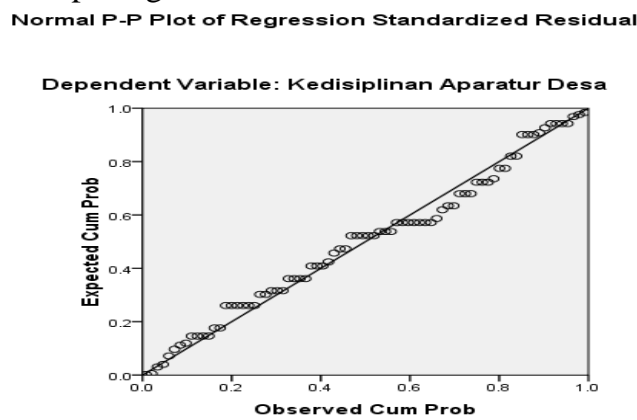

Hasil uji normalitas pada gambar 1. di atas menunjukan bahwa titik-titik bersandar pada garis diagonal artinya menunjukan pengaruh positif sehingga instrument penelitian ini layak untuk dilakukan atau dengan kata lain berdistribusi secara normal (Sugiyono, 2010).

\section{Uji Multikolinearitas}

Multikolinearitas berarti adanya hubungan linier yang sempurna atau pasti di antara beberapa atau semua variabel yang menjelaskan dari model regresi. Untuk mendeteksi ada atau tidaknya Multikolinearitas dapat diketahui dengan melihat toleransi variabel dan variance inflation factor (VIF) dengan membandingkan sebagai berikut:

a. VIF <10 maka tidak terdapat multikolinearitas

b. Tolerance $>0,1$ maka tidak terdapat multikolinearitas

$$
\text { Menurut Sugiyono (2010) Gejala }
$$
Multikolinieritas dapat dilihat dari besarnya nilai tolerance dan VIF (Variance Inflation Factor). Kedua ukuran ini menunjukan setiap variabel independen manakah yang dijelaskan oleh variabel independen lainnya. Tolerance adalah mengukur variabilitas variabel independen yang terpilih yang tidak dijelaskan variabel independen lainnya. Nilai yang dipakai untuk Tolerance $>0,1$ dan VIF $<10$, maka tidak terjadi Multikolinieritas.
Tabel 3.

Uji Multikolinieritas

\begin{tabular}{|c|l|c|c|}
\hline \multirow{2}{*}{ No } & \multirow{2}{*}{ Variabel } & \multicolumn{2}{|c|}{ Collinearity Statistik } \\
\cline { 3 - 4 } & & Tolerance & VIF \\
\hline 1 & Kepemimpinan & .362 & 2.760 \\
\hline 2 & Motivasi Kerja & .362 & 2.760 \\
\hline
\end{tabular}

\section{Uji Heteroskedastisitas}

Model regresi yang baik adalah yang tidak terjadi Heteroskedastisitas. Untuk menguji Heteroskedastisitas dilakukan dengan analisis gambar. Melalui analisis gambar suatu model regresi diangap tidak terjadi Heteroskedastisitas jika titik-titik menyebar secara acak dan tidak membentuk suatu pola tertentu yang jelas serta tersebar di atas maupun di bawah angka nol pada sumbu Y.

$$
\text { Scatterplot }
$$

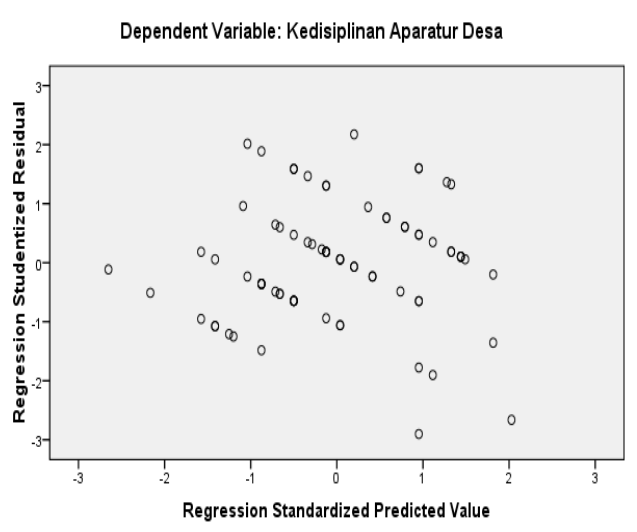

Gambar 2 memperlihatkan titik-titik menyebar secara acak dan tidak suatu pola tertentu yang jelas serta baik di atas maupun di bawah angka nol pada sumbu Y. Hal ini berarti tidak terjadi Heteroskedastisitas pada model regresi, sehingga model regresi layak dipakai untuk memprediksi prestasi kerja pegawai berdasarkan masukkan variabel independennya (Sugiyono, 2010).

\section{HASIL DAN PEMBAHASAN}

Analisis regresi linear berganda dalam penelitian ini digunakan untuk mengetahui pengaruh variabel kepemimpinan dan motivasi kerja terhadap kedisiplinan aparatur desa di kec. 
kasimbar berdasarkan pengujian diperoleh hasil sebagai berikut:

Tabel 4.

Hasil Pengujian Regresi Linear Berganda

\begin{tabular}{|l|r|r|r|}
\hline \multicolumn{1}{|c|}{ Faktor Terikat $=$ Kedisiplinan } & \multicolumn{1}{|c|}{ Aparatur Desa (Y) } \\
\hline & $\begin{array}{c}\text { Unstandar } \\
\text { dized } \\
\text { Coefficien } \\
\text { ts (Beta) }\end{array}$ & $\begin{array}{c}\text { Std. } \\
\text { Error }\end{array}$ & Sig.t \\
\hline Constant) & -1.500 & .264 & .510 \\
Kepemimpinan & .259 & .085 & .003 \\
Motivasi Kerja & .112 & .095 & .244 \\
\hline
\end{tabular}

$\mathrm{n}=78$

Konstanta $=-1.500$

Koefesien Korelasi $(\mathrm{R})=0,612$

R Square $\left(R^{2}\right)=0,374$

Adjusted R Square $=0,358$

F-Statistik $=22.434$

Sig.F $=0,000$

Dari hasil pengujian dengan menggunakan regresi linier berganda di atas, maka dapat disusun persamaan regresi berganda dari pengaruh kepempinan dan motivasi kerja terhadap kedisiplinan aparatur desa yaitu:

\section{$Y=-1.500+0,460 \times 1+0,178 \times 2$}

Hasil pengujian di atas menunjukkan, di mana nilai konstanta -1.500 yang berarti bahwa kedisipinan aparatur desa di Kec. Kasimbar sebelum adanya variabel independen adalah sebesar -1.500 .

\section{Intepretasi :}

1. Slope: Secara matematis, slope merupakan ukuran kemiringan dari suatu garis. Slope adalah koefisien regresi untuk variabel $\mathrm{X}$ (variabel bebas). Dalam konsep statistika, slope merupakan suatu nilai yang menunjukkan seberapa besar kontribusi (sumbangan) yang diberikan suatu variabel $\mathrm{X}$ terhadap variabel Y. Nilai slope dapat pula diartikan sebagai rata-rata pertambahan (atau pengurangan) yang terjadi pada variabel $\mathrm{Y}$ untuk setiap peningkatan satu satuan variabel $\mathrm{X}$.

2. Intercept : Intersep, definisi secara metematis adalah suatu titik perpotongan antara suatu garis dengan sumbu $\mathrm{Y}$ pada diagram/sumbu kartesius saat nilai $X=0$. Sedangkan definisi secara statistika adalah nilai rata-rata pada variabel $\mathrm{Y}$ apabila nilai pada variabel $\mathrm{X}$ bernilai 0 . Dengan kata lain, apabila $X$ tidak memberikan kontribusi, maka secara rata-rata, variabel Y akan bernilai sebesar intersep. Perlu diingat, intersep hanyalah suatu konstanta yang memungkinkan munculnya koefisien lain di dalam model regresi. Intersep tidak selalu dapat atau perlu untuk diinterpretasikan. Apabila data pengamatan pada variabel $\mathrm{X}$ tidak mencakup nilai 0 atau mendekati 0 , maka intersep tidak memiliki makna yang berarti, sehingga tidak perludiinterpretasikan.

Jadi :

1. Intersep sebesar -1500 secara matematis menyatakan bahwa apabila nilai X1 dan X2 sama dengan 0 maka nilai $\mathrm{Y}$ sama dengan 1500; yang berarti bahwa Kedisiplinan adalah -1500. Mana mungkin Kedisiplinan negatif???

2. Pada dasarnya intersep tidak selalu harus diinterpretasikan. Menurut Gujarati (2006) nilai intersep tidak selalu berarti karena seringkali jangkauan nilai variabel bebas tidak memasukkan nol sebagai salah satu nilai yang diamati.

3. Skala likert yang digunakan untuk kuesioner tidak memasukkan angka nol, tetapi range 1 5, sehingga variabel $\mathrm{X} 1$ dan $\mathrm{X} 2$ tidak mungkin sama dengan 0. Dengan demikian intersep yang bernilai negarif tersebut tidak perlu diinterpretasikan.

Kesimpulan:

1. Konstanta negatif tidaklah menjadi persoalan dan bisa diabaikan selama model regresi yang di uji sudah memenuhi asumsi (misal normalitas untuk regresi sederhana) atau asumsi klasik lainnya untuk regresi ganda. Selain itu, selama nilai slope tidak NOL maka tidak perlu memperdulikan konstanta negatif ini.

2. Konstanta negatif umumnya terjadi jika ada rentang yang cukup jauh antara $X$ (variabel independen) dan Y (variabel respon. misal X 
memiliki rentang nilai $1-8$, sedangkan $\mathrm{Y}$ memiliki rentang nilai $100-200$.

3. Karena dasarnya regresi digunakan memprediksi $\mathrm{Y}$ berdasarkan nilai perubahan $\mathrm{X}$, maka harusnya yang menjadi perhatian adalah X nya (slope), bukan nilai konstanta.

4. Dalam berbagai kasus, intercept juga sering tdk masuk akal untuk diinterpreasi sehingga harus diabaikan untuk kasus-kasus tertentu .

5. Jika menggunakan SPSS, coba cek garis regresi menggunakan scatter plot untuk mengetahui posisi intercept.

a. Pembuktian Hipotesis Pertama

Hipotesis pertama yaitu pengaruh kepemimpinan dan motivasi kerjaberpengaruh secara simultan terhadap kedisiplinan aparatur desa di Kec.Kasimbar.Pembuktian hipotesis pertama mengguanakan uji $\mathrm{F}_{\text {sig. Nilai signifikansi }}$ $0,000<\alpha 0,05$. Maka ini menunjukkan kedua variabel bebas yaitu pengaruh kepemimpinan, dan motivasi kerja secara simultan terhadap kedisiplinan aparatur desa di kec.kasimbar.Hal ini berarti hipotesis pertama diterima.

b. Pembuktian Hipotesis Kedua

Hipotesis kedua yaitu untuk mengetahui apakah pengaruh kepemimpinan (X1) berpengaruh positif dan signifikan terhadap kedisiplinan aparatur desa.

Dari Tabel 4 terbukti bahwa besarnya probabilitas signifikansi variabel pengaruh kepemimpinan (X1) adalah $0,003<$ taraf signifikan yang diisyaratkan $\alpha 0,05$. Dengan demikian bahwa secara statistik variabel koordinasi dalam penelitian ini memberikan pengaruh positif dan signifikanterhadap kedisiplinan aparatur desa di Kec. Kasimbar.Maka ini menunjukkan bahwa variabel bebas yaitu pengaruh kepemimpinanberpengaruh positif dan signifikan terhadap terhadap kedisiplinan aparatur desa di Kec. Kasimbar. Hal ini berarti hipotesis kedua diterima.

c. Pembuktian Hipotesis Ketiga

Hipotesis ketiga yaitu untuk mengetahui apakah variabel motivasi kerja (X2), berpengaruh positif dan signifikan terhadap kedisiplinan aparatur desa di Kec. Kasimbar.
Dari Tabel 4 terbukti bahwa besarnya probabilitas signifikansi variabel motivasi kerja(X2) adalah 0,244> taraf signifikan yang diisyaratkan $\alpha 0,05$. Dengan demikian bahwa secara statistik variabel motivasi kerjadalam penelitian ini memberikan pengaruh positif dan tidak signifikan terhadap kedisiplinan aparatur desa di kec. kasimbar. Maka ini menunjukkan bahwa variabel bebas yaitu motivasi kerjaberpengaruh positif dan signifikan terhadap kedisiplinan aparatur desa di Kec. Kasimbar. Hal ini berarti hipotesis ketiga diterima.

\section{PEMBAHASAN}

\section{a. Kepemimpinan dan Motivasi Kerja Terhadap Kedisiplinan Aparatur Desa Di Kec.Kasimbar}

Berdasarkan hasil analisis data yang telah diuraikan sebelumnya, menujukkan bahwa variabel kepemimpinan dan motivasi kerja secara bersama-sama berpengaruh signifikan terhadap kedisiplinan aparatur desa di Kec.Kasimbar.Hasil tersebut mengindikasikan bahwa kepemimpinan dan motivasi kerja dapat meningkatkan kedisiplinan aparatur desa di kec.kasimbar, hal ini bermakna bahwa hipotesis yang diuraikan sebelumnya sejalan dengan hasil penelitian ini.

Hasil analisis statistik diperoleh nilai signifikansi $(0,000)$ lebih kecil dari nilai alpha 5\% $(0,000<0,05)$. Berdasarkan hal tersebut dapat diketahui bahwa kepemimpinan dan motivasi kerja secara simultan berpengaruh signifikan terhadap kedisiplinan aparatur desa di kec.kasimbar.

\section{b. Kepemimpinan Terhadap Kedisiplinan Aparatur Desa Di Kec.Kasimbar}

Hasil analisis menunjukkan bahwa kepemimpinan memberikan pengaruh positif terhadap Aparatur Desa Di Kec. Kasimbar. Kepemimpinan yang baik diyakini mampu mengikat, mengharmonisasi, serta mendorong potensi sumber daya organisasi agar dapat bersaing secara baik. Hal ini merupakan faktor manusiawi yang mengikat sebagai suatu kelompok bersama dan memotivasi mereka dalam 
pencapaian tujuan. Kegiatan - kegiatan manajemen seperti perencanaan, pengorganisasian, dan pengambilan keputusan merupakan sebuah kepompong yang tidur (tidak aktif) sampai pimpinan bertindak untuk menghidupkan dan memotivasi dalam setiap orang dan mengarahkan mereka mencapai tujuan.

Kepemimpinan yang efektif harus memberikan pengarahan terhadap usaha-usaha semua orang yang dipimpin dalam pencapaian tujuan organisasi. Pemimpin yang efektif akan selalu berusaha agar kehendaknya diterima dan dirasakan oleh seluruh anggota kelompok sebagai kehendaknya juga. Tanpa bimbingan dari pemimpin, maka hubungan antara tujuan perseorangan dan tujuan organisasi menjadi renggang. Keadaan ini menimbulkan situasi dimana perseorangan bekerja untuk mencapai tujuan pribadinya, sementara itu keseluruhan organisasi menjadi tidak efisien dalam pencapaian sasaran-sasarannya.

Bahwa kepemimpinan berpengaruh secara langsung terhadap tingkat prestasi kerja Aparatur Desa Di Kec. Kasimbar melalui pemimpin yang memiliki peran membentuk iklim organisasi yang lebih kondusif, dari iklim yang lebih kondusif itu terbentuklah tingkat prestasi kerja pegawai yang lebih baik. Selain itu memberdayakan bawahannya agar mampu meningkatkan produktivitasnya dalam mencapai tujuan pembangunan.

Berdasarkan hasil wawancara bersama bapak zubaidi tjarungan (SEKDES), pada hari Kamis, tanggal 15 Februari 2018 pada pukul 10.00, yang mengatakan bahwa :

"Kepemimpinan partisipatif yang terjadi pada Pemerintah Aparatur Desa Kec. Kasimbar, terbuka dan mengharapkan saran-saran dari para pegawai serta menanggapi setiap saran yang disampaikan. Kemampuan pimpinan dalam melibatkan partisipasi pegawai serta mengajakn seluruh pegawai dalam mensukseskan program kerja maupun kegiatan sosialisasi tentang kependudukan. Pada indikator delegatif pada prestasi para aparatur desa kec. Kasimbar diberikan tugas sesuai bidang dan tingkat kemampuan yang dimiliki aparatur desa. Selain itu mendorong pegawai untuk terus menerus mengembangan prestasi baik dengan pendidikan formal maupun non formal.

Hal ini sejalan dengan penelitian yang dilakukan oleh Darwito (2008) yang menyimpulkan bahwa gaya kepemimpinan berpengaruh positif terhadap kinerja karyawan. Ogbonna dan Harris (2000) dalam penelitiannya menunjukkan bahwa kepemimpinan yang diperankan dengan baik oleh seorang pemimpin mampu memotivasi karyawan untuk bekerja lebih baik, hal ini akan membuat karyawan lebih hatihati berusaha mencapai target yang diharapkan perusahaan, hal tersebut berdampak pada kinerjanya. Selain itu pula didukung oleh Armanu Thoyib (2005).

\section{c. Motivasi Terhadap Kedisiplinan Aparatur Desa Di Kec.Kasimbar}

Hasil pengujian tentang pengaruh motivasi terhadap kedisiplinan aparatur sebagaimana diuraikan sebelumnya membuktikan bahwa motivasi secara parsial berpengaruh positif dan tidak signifikan terhadap kedisiplinan aparatur desa di Kec. Kasimbar.

Pemberian motivasi berarti telah memberikan kesempatan terhadap pegawai yang menjadi bawahannya sehingga pegawai bisa dan mampu mengembangkan kemampuannya. Motivasi secara sederhana dapat dirumuskan sebagai kondisi ataupun tindakan yang mendorong seseorang untuk melakukan suatu pekerjaan atau kegiatan semaksimal mungkin pegawai untuk berbuat dan berproduksi.

Peranan motivasi adalah untuk mengintensifkan hasrat dan keinginan tersebut, oleh karena itu dapat disimpulkan bahwa usaha peningkatan semangat kerja seseorang akan selalu terkait dengan usaha memotivasinya sehingga untuk mengadakan motivasi yang baik perlu mengetahui kebutuhan-kebutuhan manusia.

Hasil penelitian menunjukkan bahwa variabel motivasi mempunyai pengaruh yang signifikan terhadap kedisiplinan aparatur desa di Kec. Kasimbar. Analisa McGregor dalam Munandar (2001), menyimpulkan bahwa orang 
yang memiliki motivasi kerja yang bercorak reaktif akan cenderung mendorong mereka untuk bekerja dengan hasil yang lebih baik, karena sistem nilai pribadi (personal value sistem) mereka memprioritaskan kegiatan-kegiatan positif dalam kehidupan.

Prijosaksono dan Sembel

(2002) mengatakan motivasi bukan sekedar dorongan untuk melakukan sesuatu, melainkan sebuah seni yang melibatkan berbagai kemampuan dalam mengenali dan mengelola emosi diri sendiri dan orang lain. Paling tidak, tahu bahwa seseorang melakukan sesuatu karena didorong oleh motivasinya.

Hasil penelitian ini sejalan dengan penelitian yang dilakukan oleh Pawewang (2010) yang menemukan bahwa motivasi berpengaruh positif dan tidak signifikan terhadap Aparatur Dalam Penyelenggaraan Pemerintahan di Kecamatan Poigar Kabupaten Bolaang Mongonsow.

\section{KESIMPULAN}

\section{Kesimpulan}

Berdasarkan hasil analisis dan pembahasan, maka kesimpulan penelitian ini adalah sebagai berikut:

1. Kepemimpinan dan motivasi kerja secara simultan berpengaruh positif dan signifikan terhadap kedisiplinan aparatur desa di Kec. Kasimbar.

2. Kepemimpinan berpengaruh positif dan signifikan terhadap kedisiplinan aparatur desa di Kec. Kasimbar.

3. Motivasi kerja berpengaruh positif dan tidak signifikan terhadap kedisiplinan aparatur desa di Kec. Kasimbar.

\section{Saran}

1. Kepemimpinan perlu ditingkatkan yaitu kepemimpinan partisipatif, dengan menanggapi saran dari aparatur desa serta memperlakukan aparatur secara sama-sama guna menunjang peningkatan program yang telah dicanangkan.

2. Motivasi kerja aparatur desa di Kec. Kasimbar yang perlu ditingkatkan meliputi kebutuhan power (kekuasaan) dengan cara dapat memberikan pengaruh yang positif kepada aparatur lain dan memberikan dorongan kepada rekan kerja untuk lebih termotivasi dalam bekerja sehingga dapat meningkatkan motivasi kerja yang baik.

\section{DAFTAR PUSTAKA}

Armanu, T. (2005). Hubungan Kepemimpinan, Budaya, Strategi, Dan Kinerja: Pendekatan Konsep. Jurnal Manajemen \& Kewirausahaan, 7(1).

Azis, A. (2019). Pengaruh Citra Merek Dan Kepuasan Konsumen Terhadap Loyalitas Konsumen Sim Card Telkomsel (Studi Pada Pengguna Sim Card Telkomsel Di Ampana Kota). Jurnal Ekonomi Trend, 7(1), 71-82. Https://Doi.Org/10.31970/Trend.V7i1.174

Darwito. (2008). Analisis Pengaruh Gaya Kepemimpinan Terhadap Kepuasan Kerja Dankomitmen Organisasi Untuk Meningkatkan Kinerja Karyawan. Semarang. Universitas Diponegoro, Semarang.

Gujarati, D. (2006). Dasar-Dasar Ekonometrika. Jakarta: Erlangga.

Hasibuan, M. (2007). Manajemen Sumber Daya Manusia. Jakarta: Pt Bumi Aksara.

Hasibuan, Malayu. 2012. "Manajemen Sumber Daya Manusia". Jakarta: Pt Bumiaksara.Hasibuan,

Marjun, M. (2019). Pengaruh Di Mensi Dimensi Kualitas Layanan Terhadap Kepuasan Pasien Rawat Inap Bpjs Kesehatan Center Rumah Sakit Umum Daerah Anutapura. Jurnal Ekonomi Trend, 7(1), 12-26. Https://Doi.Org/10.31970/Trend.V7i1.170

Munandar, A. S. (2001). Psikologi Industri Dan Organisasi. Jakarta: Penerbit Universitas Indonesia.

Ogbonna, E., \& Harris, L. C. (2000). Leadership Style, Organizational Cultureand Performance: Empirical Evidence From Uk Companies. International Journal of Human Resource Management, 11, 766788.

Pawewang, A. D. (2010). Motivasi Kerja Aparatur Dalam Penyelenggaraan Pemerintahan Di Kecamatan Poigar Kabupaten Bolaang Mongonsow.

Prijosaksono, A., \& Sembel, R. (2002). Management Series. Jakarta: Pt. Elexmedia Komputindo. 
Qosim, N. (2019). Implementasi Kebijakan Pajak Reklame Dan Kontribusinya Terhadap Pendapatan Asli Daerah Kabupaten Donggala. Jurnal Ekonomi Trend, 7(2), 48-73.

Https://Doi.Org/10.31970/Trend.V7i2.180

Rivai, V., \& Sagala, E. J. (2010). Manajemen Sumber Daya Manusia Untuk Perusahaan Dari Teori Ke Praktik. Jakarta: Pt. Raja Grafindo Persada.

Robbins, S. P. (2006). Perilaku Organisasi (Kesepuluh). Jakarta: Pt. Indeks Kelompok Gramedia.

Sugiyono. 2006. "Metode Penelitian Pendidikan". Bandung: Alfabeta

Sugiyono. (2009). Penelitian Kuantitatif, Kualitaif Dan $R \& D$. Bandung: Alfabeta.

Sugiono. 2010. "Metode Penelitian Pendidikan". Bandung: Alfaabeta.

Sutrisno, E. (2011). Manajemen Sumber Daya Manusia. Jakarta: Kencana.

Yukl, G. (2009). Kepemimpinan Dalam Organisasi (5 Ed.). Jakarta: Indeks. 